\title{
The Specification of Science Education Programs in the Local Public Library: Focusing on the Programs In G-city
}

\author{
In-Ja Ahn*
}

\section{ARTICLE INFO}

Article history:

Received 15 January 2012

Revised 8 March 2012

Accepted 5 May 2012

Keywords:

Science Education Programs,

Public Library, Museum,

Exhibition, User,

National Science Museum

\begin{abstract}
The city of ' $G$ ' has been made a number of achievements with its science program as a part of public library's cultural program during the last 5 years. Recently, the national science centre has been established in the same city, the debate is now needed whether the science program in the public library have reasons to be maintained or to be reduced. The aim of this research is on the operating strategies of the science program in the public library. The research methods include case studies of operational strategies in domestic and foreign science centre, the level of satisfaction of local citizen on the science program, the vision of science program in the advancement of public library in the $21^{\text {st }}$ century. In results, the research proposes that the science program in public library should be maintained, but with locally characterised programs. In addition, the study also advised on the provision of scientific information, the strengthened search functions, and the development of user-centred services for those in science fields.
\end{abstract}

\section{Introduction}

The purpose of the public library is, as specified in the library law, an institute established to assist the information service of the public and cultural activities, reading activities, and lifelong learning. It was established for the purpose of national or local governments and is open to the public, such as public agencies, and private agencies. As such, more than $95 \%$ of domestic public libraries perform cultural programs. The themes and contents of these cultural programs include all fields, such as literature, social studies, science, and technology.

The general purposes of providing cultural programs are as follows:

1) Promote the library within the community

2) Contribute to improving the cultural life of the community users

3) Support lifelong learning of community users

4) Encourage library familiarity, use, and support

5) Alter preconceptions about libraries (static and quiet place)

6) Become the foundation for financial support to the library

7) Attempt to make local residents self-directed learners, and especially help be familiar with

* Associate Professor, Department of Library \& Children Services, Tongwon University (ijahn@tw.ac.kr) International Journal of Knowledge Content Development \& Technology, 2(1): 17-35, 2012.

[http://dx.doi.org/10.5865/IJKCT.2012.2.1.017] 
the discussion on learning

8) Expand the reading population

In addition, the more specific purposes of these cultural programs performed in the library are as follows:

1) Especially if the library is underutilized, it can be a way to promote cultural programs through the library.

2) The opportunity to develop programs which allow individual local residents to join together and foster a sense of community.

3) Children are provided a variety of learning experiences, and adults are provided opportunities for social retraining and enrichment.

Other libraries, with more specific names, such as 'Science Library', have more focused purposes, such as, in this case, the development and dissemination of Scientific and Cultural programs.

Its purpose is spreading science, culture, education, and science programs to the general public, and this purpose is discussed at length in the Royal Society 1985 annual report. The bullet points are as follows:

1) Ensuring an informed, effective workforce of science and technical fields

2) Strengthening support for science and technology

3) Facilitating decision-making on issues of social science

4) Utilizing scientific literacy in everyday life

5) Responding appropriately to the adverse effects of science and technology

The purpose of the science center, in city $G$, is to educate and work with people through the exhibits on the understanding of scientific principles. It is a place to deal with social and ethical issues related to science and technology presented through programs in the field to ordinary citizens ranging from adults to infants. The science center for this institute is meant to provide lifelong education from infants, children, youth, and citizens, but lacks sufficient programs due to the difficulties of library science center accessibility to schools, as well as an inability to meet demands of program audiences.

On the other hand, the G-city science museum is recently facing the following changes and problems:

1) The establishment of the National G-city Science Museum will expand the spaces for exhibitions and education, which will lead to an increase in visitors. G-city is expected to become a science-focused city.

2) The redevelopment of residential areas and the new establishment of an industrial complex will activate the inflow of new population with various needs in information and knowledge.

3) Current human knowledge is based on the Information system. The role of the public library is important in people entitled to education and local cultures that should be maintained and nurtured. 


\subsection{The contributions of this research}

1) The need to reposition the functions and roles of the science center in the information science library is obvious due to the establishment of the National G-city Science Museum.

2) The information and science library opened in 2002 and has been a signpost for the national libraries. Due to the external changes, it is necessary to have internal evaluations and further research on the developmental directions of the other developed libraries.

3) The educational and cultural needs of G-city are active and various, and the frequency of library usage in neighboring residences is high. Further research on library users is needed.

\subsection{Research methods}

1) The targets of library status research will include G-city, the library status in the city, and the information science library and science center, as well as their effects on the library.

2) The paper will anticipate developmental directions analyzing the operational cases of national and international science museums and centers.

3) This research will include surveys on the use and development of the public library, and the level of satisfaction of general citizens and experts.

4) This paper will also discuss visions for the library science center and cooperation methods that would be suitable for 21 st century library development.

5) The operational strategies of the information science library and science center will be presented.

The final purpose of this research is to position the functions and roles of the information science library--the combination of science museum and library--as a model of cultural facilities. Based on the cooperation with the National G-city Science Museum, G-city is expected to be a city of science, education, and culture.

\section{Science center status in information and science library of G-city}

\subsection{Concepts and roles of the science museum}

1) Concepts of the Science museum

- The science museum has been defined according to the Science Museum Support Act: “A science museum is a facility that recruits, researches, conserves, and exhibits science material and technology, and is able to spread knowledge to technical educational programs with scientific and technical information and professional staff that acquires with Article 6 paragraph 1 pursuant."

- The science museum definition according to A.S.T.C. applies to all related institutions, including the science center, scientific inquiry center, and science museum, as well as covering a wide range of science or technology related fields such as scientists, engineers, and technicians at museums, children's science museums, cosmology centers, and planetariums. Natural history 
museums, botanical gardens, zoos, and aquariums are also included.

$\circ$ According to the definition, the concept and purposes of an Information Science and Library Science Museum and Science Center, and the concept of Information Services can be considered the same.

2) The science museum's role

- The fundamental role of the G-city science museum is as follows

- Encouraging public interest in science and scientific attitudes towards values

- Improving scientific experimentation, inquiry, and the cultivation of scientific creativity

- Acknowledging the humanities and social skills and understanding scientific concepts as well as scientific and artistic recognition

- Learning Korea's natural history, status, and bright future prospects in science

- Encouraging students to strive for a career in science

- The functions of a future-oriented science museum for attaining these roles is as follows:

- Accumulating of domestic and international science and technology-related materials, publications, and information through acquisition, collection, production, conservation, management, display, distribution, exchange, and cooperation.

- Promoting natural science, science education, and science and culture by studying natural science research, science exhibitions, education, and computerized material

- Fostering the modern scientific literacy of all people, as well as youth education by creating a place for both non-formal science education and public science education.

- Supporting leisure activities, arts and physical education, and science interactions that contribute to social and cultural functions by promoting social activities such as traveling based on science culture and collaboration work between arts, sciences, and athletics

- Developing science-related books, appliances, toys, food, clothing, and souvenirs for economical benefit by relating technology and business.

- Functioning as a base for local, national, and international science and technology activities by renting the space for science and technology research and development, education, and meetings

- Functioning as a learning environment regarding nature and the history of science, status, and prospects for the establishment of a national identity

- Science museum activities suggested for fulfilling the comprehensive role of improving the quality and expanding the scope of business are listed as follows:

- Institutionalize the process of collecting and organizing scientific data, surveys, research, and information

- Provide material science exhibitions and work opportunities

- Research and develop science education programs and effective implementation of the same

- Provide a place to raise discussion of scientific performances, demonstrations, and information

- Cultivate opportunities for the life and workplace application of scientific knowledge 


\subsection{Science center operating status}

○ Students' potential scientific development begins in middle school. The advantage of mandatory science education is to raise the scientific understanding of all people, however learning only from chosen textbooks limits variety. The science museum can provide a very important education which cannot be achieved through the school system.

$\circ$ A comparison between school education and the science museum offerings

\begin{tabular}{|c|c|}
\hline School Activities & Science Museum Activities \\
\hline $\begin{array}{l}\text { Education in math, science, and technology for those } \\
\text { enrolled. }\end{array}$ & $\begin{array}{l}\text { Education in math, science, and technology for all } \\
\text { people. }\end{array}$ \\
\hline National Curriculum & Freely planned \\
\hline Mandatory & Voluntary \\
\hline Age and grade forms classes & Groups are made up of many classes \\
\hline $\begin{array}{l}\text { Administratively controlled by Ministry of Education } \\
\text { / Department of Education / School }\end{array}$ & $\begin{array}{l}\text { Randomly grouped like individuals, friends, and } \\
\text { families }\end{array}$ \\
\hline Work regularly, intentionally, and continually & Work non-periodic, sporadic \\
\hline $\begin{array}{l}\text { Convergence of knowledge in skills, and attitudes } \\
\text { which are centered around academic courses }\end{array}$ & $\begin{array}{l}\text { Various areas of knowledge, skills, and attitudes are } \\
\text { covered, which do not necessarily converge }\end{array}$ \\
\hline Almost all youth have a similar experience & Individuals have their own experience \\
\hline Evaluation for entrance examination and assessment & No standard test to evaluate ability \\
\hline purposes & Avoids complicated material and concentrates on \\
\hline $\begin{array}{l}\text { Material often difficult, uninteresting } \\
\text { Imnacting the structural understanding that knowledge }\end{array}$ & $\begin{array}{l}\text { interesting material } \\
\text { Fragmentary and shallow knowledge acauisition }\end{array}$ \\
\hline $\begin{array}{l}\text { Impacting the structural understanding that knowledge } \\
\text { is insufficient }\end{array}$ & $\begin{array}{l}\text { Fragmentary and shallow knowledge acquisition } \\
\text { A chance to see modern science and state-of-the-art }\end{array}$ \\
\hline Lack of modern science, state-of-the-art technology & technology \\
\hline Familiarize students with the function of experiments & A chance to temporarily run equipments \\
\hline Lack of Social Ministry of Culture & A chance to watch for Social Ministry of Culture \\
\hline $\begin{array}{l}\text { Not easily changing due to its conservative } \\
\text { characteristics } \\
\text { Substantial period of time will keep the current system }\end{array}$ & $\begin{array}{l}\text { New attempts to facilitate } \\
\text { A clue to self-improvement }\end{array}$ \\
\hline
\end{tabular}

- The science museum supports that which domestic science education is unable to cover. Museums are building the basic science literacy of all citizens ensuring quantity and quality of education and the potential for training scientific and technical personnel. Museums can therefore be potentially successful with the support of academic experts, the application of research and development, and widespread administrative and financial aid.

- The purpose the science library in G-city center of information science is to:

- Develop scientific thinking skills among children

- Provide educational opportunities to improve youth scientific aptitude scientific

- Recharge Scientific and technological thinking skills

- Discover and nurture gifted students early

- Increase science-friendly thinking by participating students and parents together

- Foster a sense of community

- Add new concepts to the regular curriculum. 
- Educate outside of schools, or through synergy with schools

- Local residents from all backgrounds are encouraged to participate in a variety of offered programs such as:

- Family unit exploration activities: "Mother and Child science class"

- Elementary school student exploration activities: Explore experimental science hands-on in a class titled "children's science class"

- Secondary education courses such as: "Youth Science Classroom"

- Festivals: Family science festival, "Tori Ari" of Science is held twice a year.

- Speeches: science education lectures for students and parents held six times a year with a number of experts in many scientific fields.

- Teacher training for classroom experiments: Targets kindergarten, elementary, and junior high school teachers once a month.

- Observatory: opened in July, 2004, an all-weather Planetarium used in conjunction with elementary, junior high, and high schools.

- Daily Constellation classrooms: operating automatic reflection and an articulated astronomical telescope for astronomical observation, tracking refraction equations of celestial objects according to the time.

- Parents' family constellations travel package: A program with lectures on a wide range of Astronomy and Space science topics and Astronomical observations to be held twice a year.

- Facility: Science classes are operated with 4 experimental rooms, 55 of the 62 courses related to science classes are held annually in the G-city information science library. They are for mainly children and young adults and classes are available during summer and winter vacation, as well as special lectures with one-time courses or 3 month long courses.

- The titles of the classes offered are "Experimental youth science", "Creative handicraft", "Thematic science", "Science curriculum", "Life science", and others. Five of the 62 lectures are for youth classes: "One day Exploration Classrooms", "Summer science camp", "Astronomy and Space Science CA class", Science camp, and so on. It can be assumed that classes have no difficulty attracting students.

- Surrounding institutions and synergies: Since opening, the science center has been acquired many partners and supported 27 different classes with links to other institutes. For gathering lecturers, it was supported by Elementary Teacher Research, the University Center for the Advancement of Science, and the Youth Education Center. In addition, materials from a major Korean Science and Engineering Foundation and a major supplier of educational were utilized.

- Experimental classes with kindergarten, elementary school, middle school, and high school from the province. (20 Kindergartens, 4 out of 4 elementary schools, 2 out of 2 middle schools, and 1 out of 4 high schools [Gwachoen high school]).

- Supporting staff of the science festival held in an institute of research science and invention in Gunggi province.

- Supporting staff for group sessions of highschool teachers with related classes.

- Supporting volunteers during science festival.

- Supporting Astronomy and Space Science Institute and Exhibition Association of astronomy-re- 
lated seminars and nationwide astronomical event coordination.

- Cooperation with Science lectures and instructors for scientific exercise (Youth Advancement of Science Center at Hanyang University, Astronomy and Space Science Institute, corporation youth astronomy institute).

- Utilizing received materials from outside sources and promoting science exercise.

\subsection{Science center user status}

- The science center has been operating as a series of galleries and exploration labs (gardens). User (libraries and science center) Status during the 5 year (2002-2007) cycle is as follows: reflecting the movement of the local population the number of users continues to increase and has remained constant since 2006.

\begin{tabular}{llllll}
\hline Year & Sum & Libraries & Science center & & \\
\hline Year & Sum & Libraries & Total & Museum & Labs \\
\hline 2002 & 292,859 & 220,173 & 72,686 & 48,684 & 24,002 \\
2003 & 487,984 & 338,227 & 149,757 & 104,832 & 44,925 \\
2004 & 508,505 & 359,913 & 148,592 & 108,329 & 41,200 \\
2005 & 586,889 & 437,360 & 149,529 & 79,490 & 28,554 \\
2006 & 742,516 & 636,689 & 105,827 & 79,098 & 26,729 \\
2007 & 675,284 & 569,298 & 105,986 & 81,087 & 24,899 \\
\hline
\end{tabular}

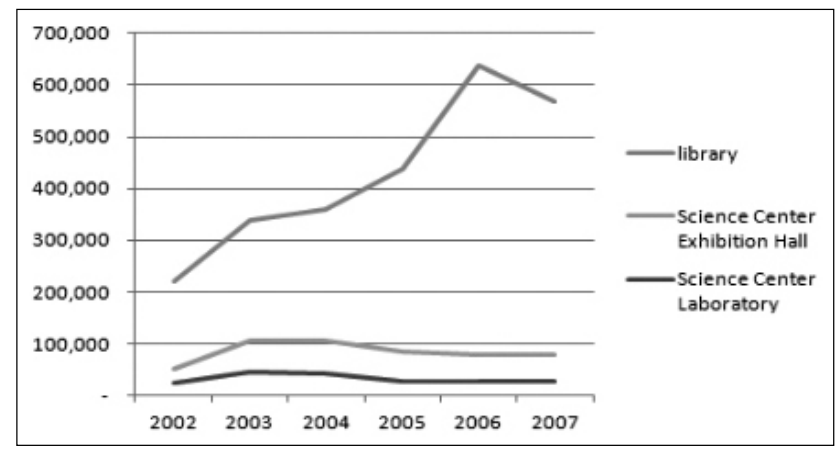

1) Exhibition usage

- Regarding the number of visitors to the science center in the museum, there was a constant increase in number of children but sharp decrease in number of youths and adults. It is deduced that the institute is suitable for children and the number of parents has increased with the number of children which can be seen in the graph. 
I. J. $A h n$

24 International Journal of Knowledge Content Development \& Technology Vol.2, No.1, 17-35 (June, 2012)

\begin{tabular}{|c|c|c|c|c|}
\hline 구분 & Visitors & & & \\
\hline Year & Children & Young Adults & Adults & Sum \\
\hline 2002 & 13,868 & 22,790 & 12,026 & 48,684 \\
\hline 2003 & 51,425 & 34,320 & 19,087 & 104,832 \\
\hline 2004 & 60,623 & 30,836 & 16,870 & 108,329 \\
\hline 2005 & 40,956 & 23,563 & 14,971 & 79,490 \\
\hline 2006 & 46,190 & 18,665 & 14,243 & 79,098 \\
\hline 2007 & 49,261 & 18,087 & 13,739 & 81,087 \\
\hline 2008 & 55,784 & 14,496 & 10,978 & 81,258 \\
\hline Sum & 318,107 & 162,757 & 101,914 & 582,778 \\
\hline
\end{tabular}

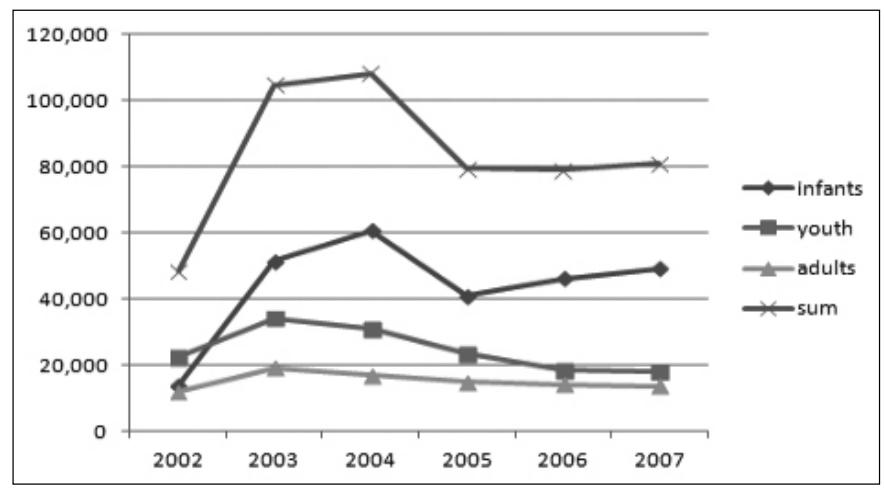

$\circ$ Exhibition users are $69 \%$ children, $18 \%$ young adults, and $18 \%$ adults. $56 \%$ of the children visited the institute as a part of group tours, and $67 \%$ of those coming were G-city users. These users visiting the library also promote G-city and the library, showing that it is an effective promoting institute.

$\circ$ On the other hand, it is a factor that increases in the proportion of off-site users.

The factor has been taken into account in the formulation of the Policy for the Library and the Science Museum.

\begin{tabular}{|c|c|c|c|c|c|}
\hline \multirow{2}{*}{ Distribution of users } & \multicolumn{3}{|c|}{ Exhibition organizations } & \multirow{2}{*}{$\begin{array}{l}\text { Personals } \\
\text { Subtotal }\end{array}$} & \multirow{2}{*}{$\begin{array}{l}\text { Sum } \\
\text { Sum }\end{array}$} \\
\hline & in-site & off-site & Subtotal & & \\
\hline Children & 10,370 & 21,058 & 31,428 & 24,356 & 55,784 \\
\hline Young Adults & 350 & 931 & 1,281 & 13,215 & 14,496 \\
\hline Adult & & & & 10,978 & 10,978 \\
\hline Sum & 10,720 & 21,989 & 32,709 & 48,549 & 81,258 \\
\hline
\end{tabular}




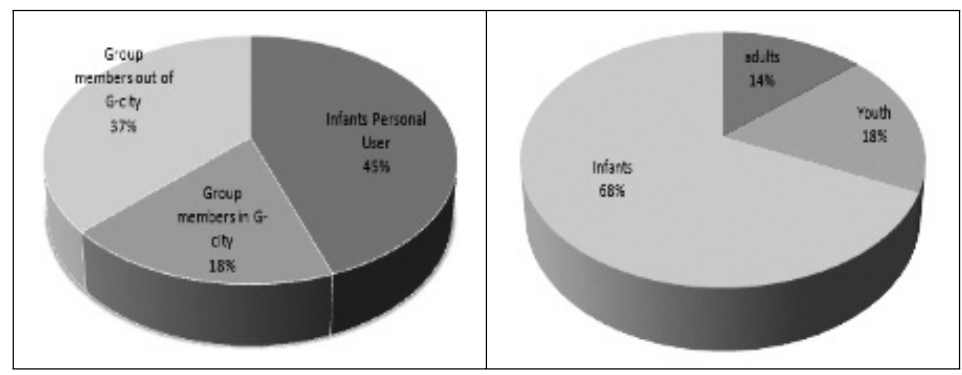

2) Exploring lab usage

$\circ$ As for lab usage in the year 2008, "mother and children science class" accounted for $46 \%$, while "children's science class" (38\%), "youth science class" (5\%), and Observatory use (11\%) were also recorded. Those classes tried to include wide ranges of different people, especially by having "mother and children class", allowing both parents and children to access the educational information and join in the session.

$\circ$ Evaluation

: The diversity and quality of offline educational programs are excellent. An online program conducted over G-City's Information Science website is "Library Information Science Nara". This site is efficient in its role as a resource for scientific institutions to operate from the center of the lab and field training programs.

However, whereas the science library collects scientific information and provides methods for its retrieval as well as information science reference and links to scientific organizations, it still lacks some basic scientific data, a lack that should be corrected.

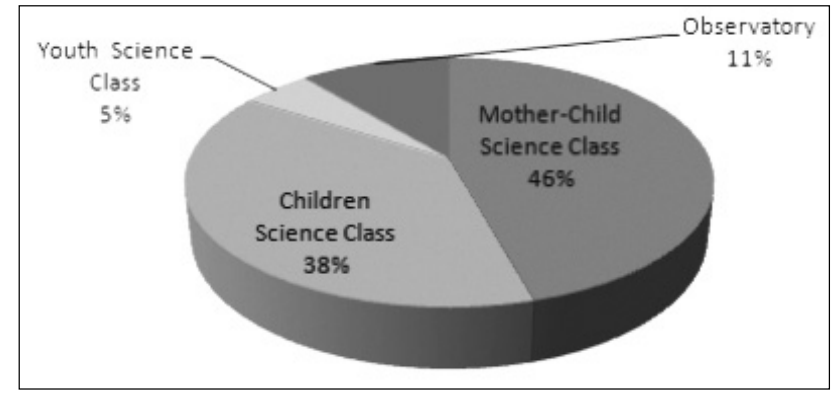

\subsection{The impact of the opening of the National G-city Science Museum}

- The National G-city Science Museum opened on Nov. 14, 2008, and started a training program for the science museum education programs and professional scientific organizations. The schedule and time table during January and February of 2009 is shown below, and the present education program is being conducted similarly to previous ones with all domestic students.

- The program has been operating for one month since opening and no long-term plans, direction, and education concepts have been approved. In addition, G-city National Science Museum 
operations and training program development team, is made up of experienced staff from the Seoul National Science Museum.

- The National G-city Science Museum can run the same program, but for better instructing students nationwide, the new program should be developed in G-city Information Science Center Library.

$\circ$ To meet existing needs, it is necessary to develop programs linked to Information Science and the Science Museum Library, incorporating both reading and science preferably with cooperation from the Science Center within the library's organization culture and team activities in G-city Information Science Library.

\begin{tabular}{|c|c|c|c|c|c|c|}
\hline \multicolumn{7}{|l|}{ Place } \\
\hline Place & Day & Wednesday & Thursday & Friday & Saturday & Sunday \\
\hline $\begin{array}{l}\text { Laboratory } \\
\text { (Chemistry) }\end{array}$ & $10: 00-12: 00$ & $\begin{array}{l}\text { Being friendly } \\
\text { with gas }\end{array}$ & $\begin{array}{l}\text { The world of } \\
\text { Chemistry } \\
\text { made with my } \\
\text { hands }\end{array}$ & & $\begin{array}{l}\text { Playing with } \\
\text { dry-ice }\end{array}$ & $\begin{array}{l}\text { Basic } \\
\text { exploration }\end{array}$ \\
\hline $\begin{array}{l}\text { Laboratory } \\
\text { (Chemistry) }\end{array}$ & $13: 00-15: 00$ & $\begin{array}{l}\text { Being friendly } \\
\text { with gas }\end{array}$ & $\begin{array}{l}\text { The world of } \\
\text { Chemistry } \\
\text { made with my } \\
\text { hands }\end{array}$ & & $\begin{array}{l}\text { Making magic } \\
\text { flower }\end{array}$ & $\begin{array}{l}\text { Basic } \\
\text { exploration }\end{array}$ \\
\hline $\begin{array}{l}\text { Laboratory } \\
\text { (Chemistry) }\end{array}$ & $15: 30-17: 30$ & & $\begin{array}{l}\text { Secret of } \\
\text { Chemistry } \\
\text { (Change of } \\
\text { material) }\end{array}$ & $\begin{array}{l}\text { Here and there } \\
\text { of Chemistry }\end{array}$ & $\begin{array}{l}\text { Basic } \\
\text { exploration }\end{array}$ & Acid and Base \\
\hline $\begin{array}{l}\text { Laboratory } \\
\text { (Physics, } \\
\text { Geography) }\end{array}$ & $10: 00-12: 00$ & Eco-Earth & $\begin{array}{l}\text { Scientific } \\
\text { experiment of } \\
\text { wonder }\end{array}$ & & $\begin{array}{l}\text { The world and } \\
\text { I }\end{array}$ & $\begin{array}{l}\text { Basic } \\
\text { exploration }\end{array}$ \\
\hline $\begin{array}{l}\text { Laboratory } \\
\text { (Physics, } \\
\text { Geography) }\end{array}$ & $13: 00-15: 00$ & Eco-city & $\begin{array}{l}\text { Generation of } \\
\text { electricity }\end{array}$ & $\begin{array}{l}\text { History of } \\
\text { Science }\end{array}$ & $\begin{array}{l}\text { Physics out of } \\
\text { textbook }\end{array}$ & $\begin{array}{l}\text { Basic } \\
\text { exploration }\end{array}$ \\
\hline $\begin{array}{l}\text { Laboratory } \\
\text { (Physics, } \\
\text { Geography) }\end{array}$ & $15: 30-17: 30$ & Eco-city & Play Physics & Fluid dynamics & $\begin{array}{l}\text { Basic } \\
\text { exploration }\end{array}$ & Make Co-town \\
\hline $\begin{array}{l}\text { Laboratory } \\
\text { (Biology) }\end{array}$ & 10:00-12:00 & $\begin{array}{l}\text { Little Science } \\
\text { community }\end{array}$ & & $\begin{array}{l}\text { Finding } \\
\text { science from } \\
\text { CSI }\end{array}$ & I am Fabre too & $\begin{array}{l}\text { Basic } \\
\text { exploration }\end{array}$ \\
\hline $\begin{array}{l}\text { Laboratory } \\
\text { (Biology) }\end{array}$ & $13: 00-15: 00$ & $\begin{array}{l}\text { Little Science } \\
\text { community }\end{array}$ & $\begin{array}{l}\text { Exploration of } \\
\text { humans }\end{array}$ & $\begin{array}{l}\text { Finding } \\
\text { science from } \\
\text { CSI }\end{array}$ & $\begin{array}{l}\text { Handling } \\
\text { microscopes } \\
\text { and cell } \\
\text { observation }\end{array}$ & $\begin{array}{l}\text { Basic } \\
\text { exploration }\end{array}$ \\
\hline $\begin{array}{l}\text { Laboratory } \\
\text { (Biology) }\end{array}$ & $15: 30-17: 30$ & & $\begin{array}{l}\text { Astronomy } \\
\text { Special }\end{array}$ & $\begin{array}{l}\text { Science class } \\
\text { for youths }\end{array}$ & $\begin{array}{l}\text { Basic } \\
\text { exploration }\end{array}$ & \\
\hline
\end{tabular}

- G-city National Science Museum uses its educational facilities to conduct educational programs as follows: 


\begin{tabular}{|c|c|c|c|c|}
\hline Program & When & Place & Object & Institute \\
\hline $\begin{array}{l}\text { Life science } \\
\text { classrooms }\end{array}$ & Throughout the year & $\begin{array}{l}\text { 6th laboratory of } \\
\text { G-city National } \\
\text { Science }\end{array}$ & $\begin{array}{l}\text { Children to middle } \\
\text { school students }\end{array}$ & $\begin{array}{l}\text { Science culture } \\
\text { foundation of } 21 \mathrm{st} \\
\text { century }\end{array}$ \\
\hline $\begin{array}{l}\text { Future scientists } \\
\text { classroom }\end{array}$ & Throughout the year & $\begin{array}{l}\text { 1st laboratory of } \\
\text { G-city National } \\
\text { Science }\end{array}$ & $\begin{array}{l}\text { Kindergarteners to } \\
\text { primary school } \\
\text { students }\end{array}$ & Four reasons, Sa-e-u \\
\hline $\begin{array}{l}\text { Scientific expedition } \\
\text { from Land of } \mathrm{Oz}\end{array}$ & Throughout the year & $\begin{array}{l}\text { 8th laboratory of } \\
\text { G-city National } \\
\text { Science }\end{array}$ & $\begin{array}{l}\text { Kindergarteners to } \\
\text { primary school } \\
\text { students }\end{array}$ & Top science \\
\hline $\begin{array}{l}\text { K-Nex robotics } \\
\text { classroom }\end{array}$ & Throughout the year & $\begin{array}{l}\text { 2nd laboratory of } \\
\text { G-city National } \\
\text { Science }\end{array}$ & $\begin{array}{l}\text { Kindergarteners to } \\
\text { primary school } \\
\text { students }\end{array}$ & Brain builder \\
\hline $\begin{array}{l}\text { High-touch, } \\
\text { high-tech } \\
\text { experimental science } \\
\text { classrooms }\end{array}$ & Throughout the year & $\begin{array}{l}\text { 2nd laboratory of } \\
\text { G-city National } \\
\text { Science }\end{array}$ & $\begin{array}{l}\text { Children to middle } \\
\text { school students }\end{array}$ & $\begin{array}{l}\text { Science Education of } \\
\text { Seo-ee }\end{array}$ \\
\hline $\begin{array}{l}\text { Thinking science and } \\
\text { mathematics of } \\
\text { SKI-O }\end{array}$ & Throughout the year & $\begin{array}{l}\text { 4th laboratory of } \\
\text { G-city National } \\
\text { Science }\end{array}$ & $\begin{array}{l}\text { Kindergarteners to } \\
\text { middle school } \\
\text { students }\end{array}$ & $\begin{array}{l}\text { SKI-O } \\
\text { Science gifted people }\end{array}$ \\
\hline $\begin{array}{l}\text { Gifted robot Science } \\
\text { and Doctor of } \\
\text { electricity }\end{array}$ & Throughout the year & $\begin{array}{l}\text { 3rd laboratory of } \\
\text { G-city National } \\
\text { Science }\end{array}$ & $\begin{array}{l}\text { Kindergarteners to } \\
\text { primary school } \\
\text { students }\end{array}$ & Top Kit \\
\hline $\begin{array}{l}\text { Donga Science } \\
\text { science lab 'Joy LAB' }\end{array}$ & Throughout the year & $\begin{array}{l}\text { 1st laboratory of } \\
\text { G-city National } \\
\text { Science }\end{array}$ & $\begin{array}{l}\text { Kindergarteners to } \\
\text { primary school } \\
\text { students }\end{array}$ & Dong-A Science \\
\hline
\end{tabular}

- The scale of the Science Museum and its foundational purposes ensure no duplication of exhibits. User Status has not changed since the opening of the National G-city Science Museum.

\begin{tabular}{llll}
\hline Division & Day average & Weekdays average & Weekend average \\
\hline Before & 285 & 259 & 312 \\
After & 286 & 336 & 234 \\
\hline
\end{tabular}

\section{Domestic and foreign science museum and science center operating practices}

\subsection{Classification of the science museum}

- The establishment of a science museum is divided between national, public, and private, depending on the establisher and institution, and as a general or special science museum, depending on its categories and functions. The national science museums can be either central or local, and private museums can be categorized as either corporate or individual museums.

$\circ$ The general science museums target the entire population, dealing with all fields and levels, including nature, science, and technology, while the special science museums target specialized and focused populations or fields in science. 
$\circ$ Based on the Science Museum Supporting Law, Clause 3, science museums are divided as follow depending on the main body of establishment and operation:

- National G-city science museum: established and operated by the government

- Public science museum: established and operated by the local government

- Private science museum: established and operated by a corporation, organization, or individual

Museums are also divided as follow depending on their target population and functions

(1) General science museum

- National general science museum eg. National Museum of Korea, National Seoul Science Museum, National G-city Science Museum

- Public science museum eg. Science Centre in G-city information science library

- Private science museum

(2) Special (educational) science museum

- Total 16 national and local education offices targeting students

Eg. science museum in Gangwon Science education research centre

(3) Special (theme) science museum

- National theme science museum eg. Agricultural science museum, rain forest science museum

- Public theme science museum eg. Gosung dinosaur museum

- Private theme science museum eg. Korea communication science museum, Sinla history science museum, Nail-Sung Science Museum

(4) Special (University/college) science museum

- Established and operated by a university or college eg. Seoul National University medical science museum, Ehwa Women University's Museum of Natural History

\subsection{The distribution of domestic science museums}

- In 2005, there were 9 national, 44 public, 34 private, and 9 university/college science museums, which made up to 96 domestic science museums in total.

\begin{tabular}{lllll}
\hline & General Museum & Educational Museum & Theme Museum & Sum \\
\hline National Institute & 2 & - & 7 & $9(9 \%)$ \\
Public Institute & - & 17 & 27 & $44(46 \%)$ \\
Private Institute & 1 & - & 33 & $34(35 \%)$ \\
Academic Institute & & & 9 & $9(9 \%)$ \\
Sum & 3 & 17 & 67 & 96 \\
\hline
\end{tabular}

$\circ$ The number of National museums are as follows: 
I. J. Ahn

International Journal of Knowledge Content Development \& Technology Vol.2, No.1, 17-35 (June, 2012)

\begin{tabular}{llllll}
\hline County/City & $\begin{array}{l}\text { General } \\
\text { Museum }\end{array}$ & $\begin{array}{l}\text { Educational } \\
\text { Museum }\end{array}$ & $\begin{array}{l}\text { Theme } \\
\text { Museum }\end{array}$ & $\begin{array}{l}\text { Academy } \\
\text { Museum }\end{array}$ & Sum \\
\hline Seoul & 2 & 2 & 5 & 3 & 12 \\
Geung ggi & 0 & 1 & 11 & 0 & 12 \\
Incheon & 0 & 1 & 3 & 0 & 4 \\
Gangwon & 0 & 1 & 10 & 0 & 11 \\
Chungbuk & 0 & 1 & 4 & 0 & 5 \\
Chungnam & 0 & 1 & 5 & 0 & 6 \\
Daejun & 1 & 1 & 3 & 2 & 7 \\
Geungbuk & 0 & 1 & 8 & 1 & 10 \\
Daegue & 0 & 1 & 1 & 1 & 3 \\
Geungnam & 0 & 1 & 4 & 0 & 5 \\
Pusan & 0 & 1 & 4 & 1 & 6 \\
Ulsan & 0 & 1 & 1 & 0 & 2 \\
Junbuk & 0 & 1 & 1 & 0 & 2 \\
Junnam & 0 & 1 & 6 & 0 & 7 \\
Gwangju & 0 & 1 & 0 & 1 & 2 \\
Jeju & 0 & 1 & 1 & 0 & 2 \\
Sum & 3 & 17 & 67 & 9 & 96 \\
\hline
\end{tabular}

- There are 76 total national theme science museums dealing with specialized science. The theme science museums in Gyeonggi-do are as follows:

\begin{tabular}{llll}
\hline Area & National Institute & Public Institute & Private Institute \\
\hline Seoul & National Agricultural & Sedaemun Natural History & Agricultural Museum \\
& Museum & Museum & Robot Museum \\
& & & Samsung Children's Museum \\
Gyeonggi & Forest Museum & Water Museum & IT World, KT Science Museum \\
& Train Museum & Nature Eco-Museum & Yeoju Silk Yarn Folk Museum \\
& & Seoul Park Forest & Nature history Museum Yusekhen \\
& & Exhibition & Yangpyeong Nature Ecological Museum \\
& & & Haneul Science Theme Museum \\
Incheon & -- & - & Gaonghwa Eunam Nature history Museum \\
& & & KT Gas Company Science Museum \\
& & & Insect Museum \\
\hline
\end{tabular}

\subsection{The types and scopes of providing services}

- The services provided by science museums are exhibition, education, and events. These include special exhibitions based on novel ideas, education programs of various topics and research opportunities, and science events that attract the public interest.

- The exhibitions are divided into permanent and special exhibitions. For example, 'Study unit' in the National Museum of Korea is holding a permanent exhibition on the spaces that allow visitors to experience the basic principles of science. The special exhibitions in the National 
Museum of Korea showcase cultural and art related materials as well as scientific technologies (eg. National Science Exhibition, National Student Competition of Invention, Special Exhibitions on Personal Collection, Seoul National Science Museum's 'the mystery of the human body'). - There has been high interest in various educational programs such as education in the science museum and experiencing education. Various educational activities related to exhibition topics in science museums are now being attempted.

- National Museum of Korea : offers astronomical science class, computer class, science research class, Robo-lab class, Lego-doctor class, student science class, science camp, student computer class, general housewives' computer class, domestic science class and others.

- Mokpo Natural History Museum: running ecological experience programs for curators with different specialties.

- Dinosaur Museum in Gosung, Gyeungnam: holds a camp on dinosaurs, footprints, and fossiliferous stratum.

- Natural History Museum in Gyeryong Mountain: running various educational programs on minerals, insects, and dinosaurs.

- Busan Marine Natural History Museum: holds an exhibition on marine organism specimens and models, with Braille explanations for the blind.

- Limitations and tasks

- Exhibitions: maintenance of worn-out exhibits, insufficient development of exhibiting contents due to lack of research, lack of exhibiting spaces, lack of budget for exhibition changes, and lack of professional experts.

- Education: outdated educational facilities and equipment, insufficient variety of educational contents, lack of science lecturers for the general population, lack of connectedness with schools, and lack of experts for educational programs.

- Informatization : computer lab, databases, and multimedia systems need to be revised, the establishment and activation of DB based on developed science museum cases are essential factors.

- Management: marketing activities of science museums, insufficient budget management, and the accessibility of museum are important factors.

\subsection{The operational status of international science museums}

These results are based on the analysis of 2004 ASTC (Association of Science Technology Centers Incorporated) reports on 185 science museums in 22 countries.

- In the U.S.A, science museums consist of $81 \%$ of city-run non-profit organizations and $15 \%$ of national or local institutions, while in other countries they are $52 \%$ of city-run non-profit organizations, $39 \%$ of national level institutions, and $9 \%$ of local institutions.

- The major annual visitors are part of student groups, as are $23 \%$ of total visitors in foreign science museums.

- Among foreign museums, 33\% have large-sized screens, 35\% have planetariums, and 32\% have outdoor exhibition rooms or science parks. 
I. J. Ahn

International Journal of Knowledge Content Development \& Technology Vol.2, No.1, 17-35 (June, 2012)

- Some $83 \%$ of museums have school visiting programs, and $76 \%$ research curriculum contents. In the U.S.A, museums running after-school programs have increased from $47 \%$ to $58 \%$ in two years. Some $68 \%$ of museums research homeschool materials, and $27 \%$ run programs for the elderly.

- Among the participating institutions, $88 \%$ have paid admissions, at $\$ 7$ median for an adult, and $\$ 5$ for a child, while domestic fees are at 1000 Won for an adult and 500 Won for a child.

- $88 \%$ of the participating institutions are membership based, with 2400 members and $60 \%$ renewal rates.

- From the perspective of exhibiting space, large-sized museums have 139 full-time employees, 7 part-time and 268 volunteers. $90 \%$ of the participating institutions had volunteer programs, while the U.S.A had higher numbers of volunteers than employees.

- Among the total income, direct donations (46\%) were the largest, followed by, public funds, revenue (27\%), private fund revenue (24\%), and asset income (about $3 \%$ ).

- Budgets were spent on first labor, then publicity, and fundraising. In the the United States, the recruiting budget was larger than that for publicity.

- Among the visitors, the institute with the greatest proportion of school visits was Australia's Questacon (33\%), followed by Future Museum of Japan (27\%) and the Denver Science Museum of the United States.

\subsection{Case comparison}

- G-city Information Science is a special formation of a public science museum combined with a library.

- Exhibitions: the limitations are similar with other institutions, such as maintenance of worn-out exhibits, insufficient development of exhibiting contents due to the lack of research, lack of exhibiting spaces, lack of budget on exhibition changes, and lack of professional experts.

- Education: educational facilities and equipment, the variety of educational contents, and school connectedness are all at a far higher level than those offered at other institutions. In addition, the problems in securing experts for educational programs have been solved by cooperating with domestic educational institutions and educational experts. However, there has been a lack of science lecturers for the general population, as seen in other facilities.

- Informatization: this is the biggest limitation, as an information science library. The computer lab, databases, and multimedia systems need to be renovated, based on developed science museum cases.

Connectedness with G-city National Science Museum: this science center has similar operational purposes and size with G-city National Science Museum. It is essential to review the response of users over a longer term. In addition, since G-city National Science Museum is at the beginning stages of its educational programs, this science center currently has a higher level of variety and accumulated educational information; co-operational developments based on partnerships with G-city 
National Science Museum can be encouraged.

\section{Science center operations plan}

\subsection{Science center operating strategy}

$\circ$ When the library opened in 2002 with the science inquiry garden (the lab) and the Science Exhibition Science (science amusement park, the garden experience), it was nominated as one of the best libraries to be benchmarked.

- On the other hand, due to the National G-city review of the Science Museum, Nov. 14, 2009, there was a relative decline in the value due to the high cost of maintaining aging science exhibits and evaluation on competitive, related educational programs. Reordering the contents of scientific inquiry is perhaps necessary, but on the other hand, because it has been only 2 months since the review of the National G-city science museum, the center also needs to observe the situation.

- It has become necessary to complement and modify the function of basic science centers.

- Offline and online library science programs on offer are as follows:

(1) If science program implementation and events are conducted, it must be determined whether they are based on the following operating standards. Furthermore, event program operating standards shall be as follows:

- Science Center-related research, education, and programs will promote the development of science and culture and cultural industries

- Social programs, offered as an educational institution, to meet the educational needs of the general public and to complement data collection, preservation, research, as well as exhibitions, lectures, debates, and various educational programs

- Programs to contribute significantly to the local culture of the community as a key cultural facility

(2) Using the information science and technology of the country's current homepage to build a science portal site for the youth would accomplish many jointly held goals. Such a portal site would play a fundamental role as a scientific library of information science, using the navigation technology and DB of LG Science Land to target this age group. Possible functions could include the ability to search for scientific information integration services and general topics, multimedia content, and video files in accordance with the 7th National Curriculum created by the Ministry of Education.

(3) The analysis of youth user behavior can be configured through research into information, navigation, science videos, science careers, science games, science club introduction, and science teacher recommended sites. 


\begin{tabular}{|c|c|c|}
\hline Class & Sub class & Contents \\
\hline Information search & A closer look at subjects & $\begin{array}{l}\text { Find information about Physics, Chemistry, } \\
\text { Biology, and Earth Science }\end{array}$ \\
\hline Information search & Searching for information & Search by using a meta-search engine search \\
\hline Information search & Science News & Collection of science NEWS \\
\hline Information search & Science dictionary & Encyclopedia search of scientific field \\
\hline Curiosity of Science & Science IQ & Video files of sports and other contents \\
\hline Curiosity of Science & Science Experiments & Video files of Scientific experiments \\
\hline Curiosity of Science & Solution for curiosity & FAQ on internet \\
\hline Being a scientist & Career and job opportunities & Job opportunities in science-related fields \\
\hline Being a scientist & Science gifted corner & Education information for the gifted \\
\hline Being a scientist & $\begin{array}{l}\text { Science and Information Literacy } \\
\text { Education }\end{array}$ & $\begin{array}{l}\text { Education information for scientific field } \\
\text { information usage }\end{array}$ \\
\hline Playing with science & Scientific games & Contents: games and science \\
\hline Playing with science & Science quiz & Quiz on Science \\
\hline Science clubs & Homepage of Science teachers & Guidance for Science teachers \\
\hline Science clubs & Science circle & Community of common interest \\
\hline Science clubs & Web site guidance & $\begin{array}{l}\text { Website guide for excellent domestic and foreign } \\
\text { science-related fields }\end{array}$ \\
\hline
\end{tabular}

\subsection{Science and education networks and operations}

- Participating institutions : G-city Information Science Library, Gyeonggi Science Education, National G-city Science Land Science Museum, LG, and Korea Science and Engineering Foundation

- Gyeonggi-do Science Education: Educational researchers supporting science, and resources and operating base

- Annual program evaluation with experts

- Support from the relevant authorities for education programs and instructors

- Web sites that can be built for youth for Information Science Assistance

\subsection{Proposal for science museum education programs}

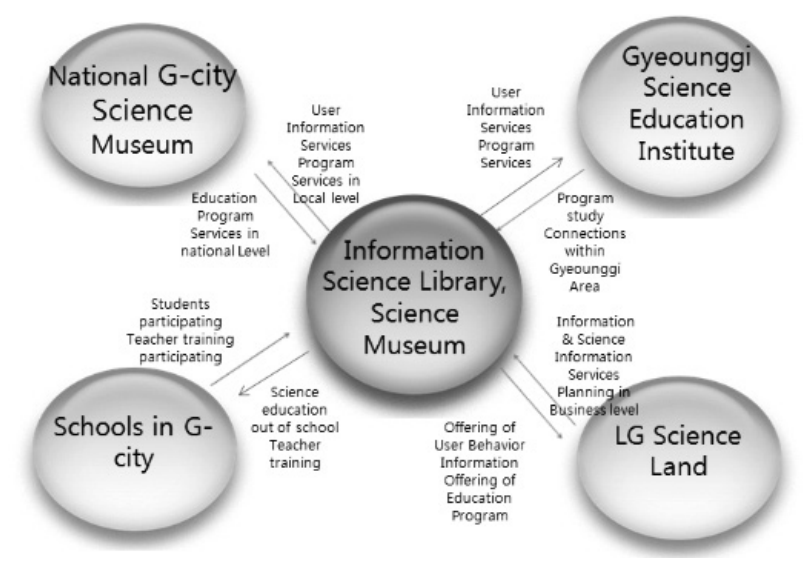


- Some possible science programs for youth are as follows. The following can be available in small institutes right up to the national government level, which can be the basis of the program foundation.

- Youth Scientific Award:

The CREST model is being successfully implemented in the United Kingdom and Australia, and it can be transformed accordingly to the South Korean situation. It is to award students with a certificate to recognize their efforts in scientific achievements during their time spent on experiments at certain standard level. It is different from a competitive award system.

- National Science Club Union: a national science club organization which could be organized such as the British BAYS and Australian HELIX. It would support children in their cooperative science activities and could provide opportunities for that purpose.

- Science journalist training program: AAAS from the United States offers internship programs for 10 week to gain work experience in the field of newspapers, news magazines, and broadcasters to improve science journalism training. This can be applied as a practice program.

- Research on regular forum for business, culture, science, and evaluation: there will be a forum to promote personnel participation for those who are related to the UK's annual COPUS forum which holds science festivals of culture and science and business meetings.

- Science Exploring in Korean History : The package tour to help explore and experience Korean history through relics and historical sites will be developed as a media guide.

- Joint science exploration debate tournament: The candidates (who should be older than primary school students) will be judged by aspects of cooperating, performing to the objective, and discussing. This tournament should, in principle, provide an open exploration of the issues prior to the tournament.

\subsection{Exhibition hall suggestions}

- Usage of current exhibits, as shown in 2.4.2, rather than overall G-city users, the number of local children's groups living nearby make up the majority of guests and visitors, but overall the number of visitors is decreasing. In addition, there is 70 million won budgeted annually for maintenance. Therefore it would be desirable to move the children's room to the children's area of the current library for enlargement.

$\circ$ When planning a new children's library, some of the exhibits should be displayed within the library. Scientific books and magazines related to children's interests in material science are also scheduled to be exhibited.

- It would be advantageous to have storytelling for children in the children's room of the library. - Since current exhibits are still worth utilizing, they need either to be donated to the school library or other areas near the Children's Library and let nearby local municipalities co-manage them. 


\section{References}

Gwachon City Information Science Library. (2008). The Middle -Long Term Developing Planning of Gwachon city Information Science Public Library. 